\title{
What Are the Drivers of The Romanian Transport Services Exports?
}

\author{
Anca TAMAȘ \\ The Bucharest University of Economic Studies, Romania \\ anca.tamas@rei.ase.ro
}

Received date:21 July 2020; Accepted date: 23 December 2020; Published date: 18 January 2021

Academic Editor: Burlacu Oana Steliana

Copyright (C) 2021. Anca TAMAȘ. Distributed under Creative Commons Attribution 4.0 International CC-BY 4.0

\begin{abstract}
The purpose of this paper is to assess the main drivers of the Romanian transportation services export flows. The methodology included 12 years and 137 countries, it was based on the gravity model and the panel approach was considered. For the panel regression, EViews 10 was used. Panel Least Squares Cross section SUR, Panel Least Squares Cross section fixed effects and Robust Least Squares options were considered. The major findings were the following: the economic size, measured by the GDP and the unemployment rate of the receiving country, cultural similarities, like common border and common language, as well as EU membership, have a positive impact on the Romanian transportation services export flows. The geographical distance has a negative, small influence on the transportation exports. The Logistics Performance Index, the Consumer Price Index and the Landlocked of the partner country are not statistically significant. The main practical implication is the fact that the Romanian transportation services exports could increase because the potential exports are greater than the real ones. The major drivers of the Romanian transportation export flows are the openness to transport services and the services trade openness of the partner country. The limitation of the paper is referring to the lack of data for the Logistics Performance Index.
\end{abstract}

Keywords: gravity model, transportation services exports

JEL Classification: F14: Empirical Studies of Trade;

C33: Panel Data Models; Spatio-temporal Models

Cite this Article as: Anca TAMAȘ (2021)," What Are the Drivers of The Romanian Transport Services Exports? ", Journal of Eastern Europe Research in Business and Economics Vol. 2021 (2021), Article ID 359892, DOI: $10.5171 / 2021.359892$ 


\section{Introduction}

\section{Literature Review}

Ever since it was introduced by Jan Tinbergen in 1962, the gravity model became the most successful, popular and reliable model to study the trade flows between two countries. The model took its name from the Newton's gravity law: the forces between two particles are positively influenced by their masses and negatively influenced by the square of their distance. The economic translation would be that the trade flows between two countries are positively influenced by the size of their economies and negatively influenced by the distance between them. At first, the model was applied based on this intuitive, simple and even beautiful economic application of the gravity laws. The theoretical foundations were established later on starting with Anderson (1979), Krugman (1980), Bergstrand (1985), Helpman (1987), Deardorff (1998), Baier and Bergstrand (2001), Evenett and Keller (2002), Anderson and van Wincoop (2003), Head (2003), Feenstra (2003), Rose and Spiegel (2004), Brun et al (2005), Martinez-Zarzoso and Suarez-Burguet (2005), Baldwin and Taglioni (2006), Egger (2008), Anderson (2010). Deardorff (1998) considered the gravity model as a fact of life, this is why it fits with all trade models, and Head and Mayer (2014) said the gravity model is the workhorse, the toolkit and the cookbook for trade research. So far the researchers of trade flows for goods who used gravity models agreed on some issues: the economic size, measured by GDP or GDP per capita, has a positive impact on the trade flows, while the distance between countries has a negative impact. As for dummy variables, sharing a common border, a common language or an economic union membership positively influences the trade flows. The controversy persists on the range for the values of the coefficients or on the methodology used and new results come from introducing further determinants of the trade flows.
But when it comes to services trade flows, things are quite different. The first study referring to services trade flows was the one of Francois (2001), the methodology was further developed by Francois et al (2003), secondly the literature on the services trade flows is scarcer compared to the one on goods trade flows and it is more controversial as well.

According to Francois (2001), only the GDP of the receiving country influenced the services imports, but Grunfeld and Moxnes (2003) found that the GDP of the importers and the GDP per capita of the exporters matter too. The GDP per capita is an important determinant for the importers and the exporters as well (Walsh, 2006).

According to Grunfeld and Moxnes (2003), the distance between countries has a negative impact on the services trade flows and, according to Park (2002), it is significant for all services considered, but Tharakan et al. (2005) found the distance to be insignificant for Indian software services exports. Kimura and Lee (2006) found that the distance is more important for services than it is for goods trade flows, while Lejour and de Paiva Verheijden (2004) found the distance less important for services compared to goods. The distance was not considered a significant determinant for services flows (Walsh, 2006). Geographical distance influence is greatly reduced for online services (Alaveras and Martens, 2015) and not so important for air transportation services (Yamaguchi, 2008).

Park (2002) found a common language important for services trade flows, yet Kimura and Lee (2006) disagreed. Kox and Lejour (2005) found that sharing a similar language increases the services trade level. A common language was found as an important determinant for services by Walsh (2006) and by Nordas (2018). Sharing a common language was found important for passenger transportation services (Tsui and Fung, 2016). 
The membership in a free trade area (FTA) is not significant in the case of services (Grunfeld and Moxnes, 2003), and Kimura and Lee (2006) found FTAs to be positively correlated with the services trade flows. EU membership is not as important for services as it is for goods flows (Walsh, 2006). An FTA with a similar country has a positive impact on the services flows (Nordas, 2018).

According to Walsh (2006), sharing a common border doesn't increase the services trade flows, while Nordas (2018) considered that a common border almost triples the trade.

The comparative advantage of the home country was found to be important for services exports (Alaveras and Martens, 2015).

Transportation services are among the most protected in developed and developing countries as well (Borchert et al, 2012).

The Logistic Performance Index (LPI) created by the World Bank is used as a proxy variable for trade facilitation. The exporter logistics performance seems to be more important than the importer logistics performance (Host et al, 2019).

Remoteness of the receiving country is not significant for transportation services (Covaci and Moldovan, 2015).

All in all, services trade flows are better predicted by the gravity model than the goods trade flows (Kimura and Lee, 2006).
The gravity model has been successful in explaining the international transportation trade (van Bergeijk and Brakman, 2011).

EViews 10 was used in three models, cross section SUR, cross section fixed effects and Robust Least squares.

In the cross-section SUR model, EViews estimates a feasible GLS specification, correcting for heteroskedasticity and contemporaneous correlation.

Robust least squares are referring to a variety of regression methods designed to be robust or less sensitive to outliers.

Rose and Spiegel (2004) considered the cross section fixed effects as the best fit.

\section{Romanian transport services exports between 2007 and 2018}

When analyzing the Romanian export values in 2018 compared with the corresponding values in 2007 using the data from International Trade Centre (ITC) and from World Bank, one can see that all exports almost doubled in value (1.99), the services export values are slightly more than double (2.14), while transportation exports almost tripled their value (2.99), that shows the increasing importance of transportation services exports. The share of transportation exports in services exports grew from $20 \%$ to $30 \%$ and the share of transportation exports in all exports grew from $5 \%$ to $10 \%$.

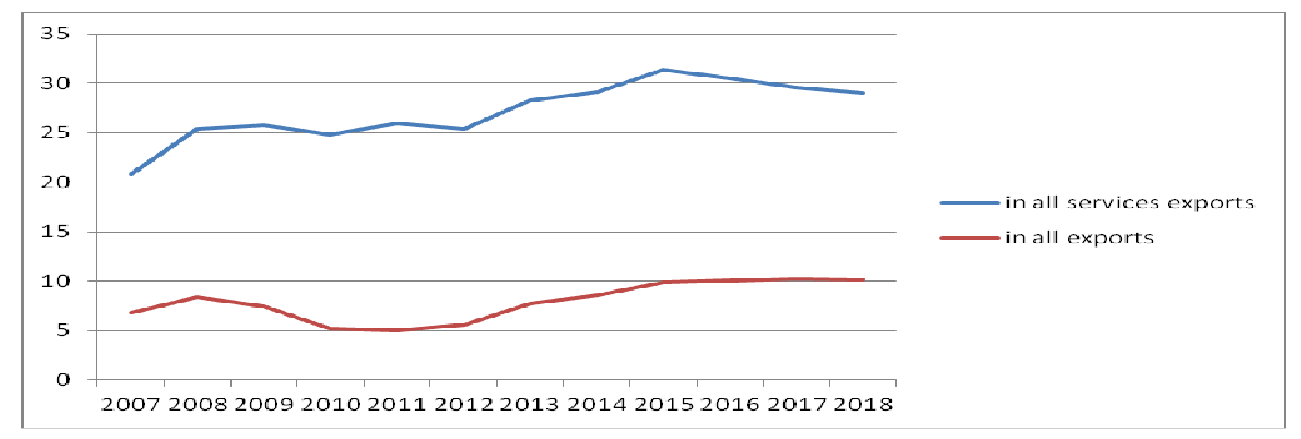

Fig. 1: The evolution of the Romanian transportation export values between 2007 and 2018

Source: International Trade Center, https://www.intracen.org/itc/market-info-tools/trade-statistics/

Anca TAMAȘ, Journal of Eastern Europe Research in Business and Economics, DOI: $10.5171 / 2021.359892$ 
In the considered period of time, most of the Romanian tranportation exports are to
EU countries, from $77 \%$ in 2007 to $92 \%$ in 2018.

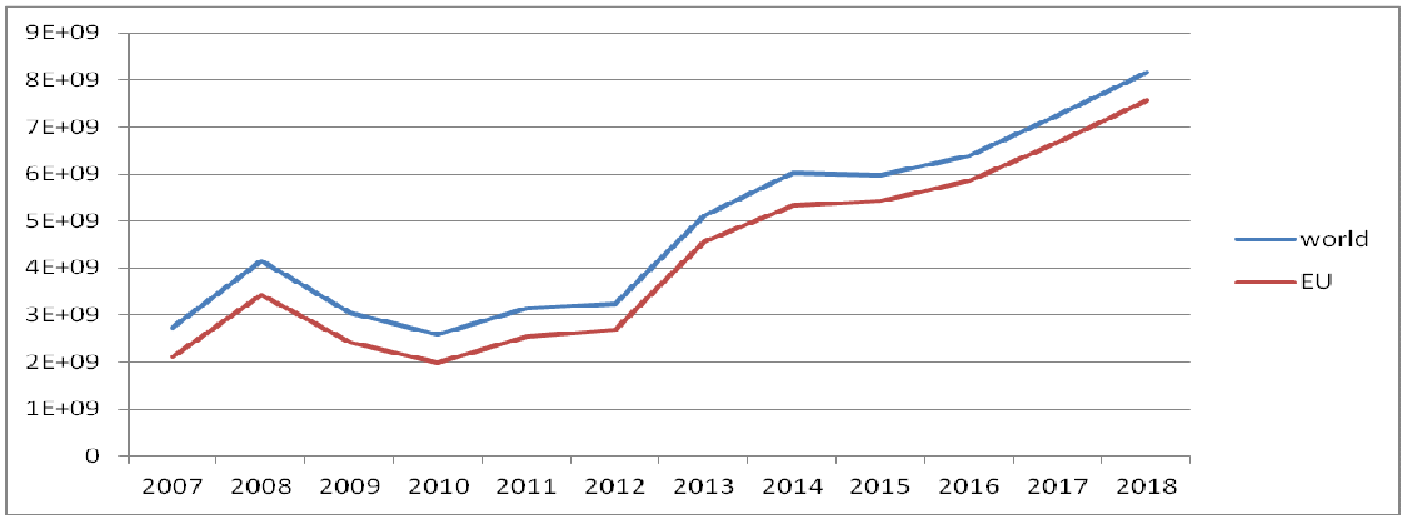

Fig. 2: Romanian transportation exports in 2007-2018

Source: International Trade Center, https://www.intracen.org/itc/market-info-tools/trade-statistics/

Although the number of countries where Romanian transportation exports went to increased from 16 to 56 , the top three receiving countries is rather constant.

Table 1: Top three countries for the Romanian transportation exports 2007-2018

\begin{tabular}{|c|c|c|c|c|c|c|}
\hline $\mathbf{2 0 0 7}$ & $\mathbf{2 0 0 8}$ & $\begin{array}{c}\mathbf{2 0 0 9 -} \\
\mathbf{2 0 1 0}\end{array}$ & $\mathbf{2 0 1 1}$ & $\mathbf{2 0 1 2}$ & $\mathbf{2 0 1 3}$ & $\begin{array}{c}\mathbf{2 0 1 4 -} \\
\mathbf{2 0 1 8}\end{array}$ \\
\hline UK & UK & UK & UK & UK & Germany & Germany \\
\hline USA & Hungary & Canada & Hungary & Hungary & Italy & Austria \\
\hline Swizerland & Bulgaria & Hungary & Canada & Swizerland & Austria & Italy \\
\hline
\end{tabular}

Source: International Trade Center, https://www.intracen.org/itc/market-info-tools/trade-statistics/

\section{Methodology}

The aim of this paper is to find the major drivers for the Romanian transportation services exports from 2007 to 2018.

The main research hypotheses are:

H1: The economic size of the partner country has a positive impact on the transportation exports.

H2: The geographical distance between countries has a negative small impact on the transportation export flows.

H3: The major drivers of the Romanian transportation export flows are the openness to transport services and the services trade openness of the partner country.
H4: The unemployment rate and the importance of transport services in the imports for the receiving countries have a positive impact on the transportation export flows.

H5: Sharing a common border, a common language or an EU membership have a positive influence on the transportation exports.

H6: The Consumer Price Index and the fact that the partner country is landlocked negatively influence the transportation export flows.

H7: The comparative advantage for Romania and the Logistic Performance Index for the receiving country positively influence the transportation exports.

Anca TAMAS, Journal of Eastern Europe Research in Business and Economics, DOI: $10.5171 / 2021.359892$ 
The gravity equation is:

$$
\begin{aligned}
& \text { LNEXPVAL }_{\mathrm{t}}=\mathrm{C}+\mathrm{c}_{1} \text { LNGDPP }_{\mathrm{t}}+\mathrm{c}_{2} \mathrm{LNDIST}+ \\
& \mathrm{c}_{3} \text { LNEXPPRODS }_{\mathrm{t}}+\mathrm{c}_{4} \mathrm{LNTSSGDP}_{\mathrm{t}}+ \\
& \mathrm{c}_{5} \mathrm{LNTSIMP}_{\mathrm{t}}+\mathrm{c}_{6} \mathrm{LNUNEMP}_{\mathrm{t}}+\mathrm{c}_{7} \text { LNCP }_{\mathrm{t}}+\mathrm{c}_{8} \\
& \mathrm{CB}+\mathrm{c}_{9} \mathrm{CL}+\mathrm{c}_{10} \mathrm{EU}+\mathrm{c}_{11} \mathrm{LL}+\varepsilon
\end{aligned}
$$

LNEXPVALt is the dependent variable, it means (the logarithm of) the value of the Romanian transport services exports in US dollars. The data were collected from International Trade Centre (ITC). The independent variables were:

LNGDPP $_{t}$ (the logarithm of) is the GDP of the partner countries; it measures the economic size of the partner countries in year t. Other variables were tested as well, GDPT (the sum of the GDP of Romania and of the partner country), GDPPC (the GDP per capita of the partner country), GDPPCT (the sum of the GDP per capita of Romania and of the partner country), but GDPP proved to have the greatest explanatory power. The data were collected from World Bank database.

LNEXPPRODS $_{\mathrm{t}}$ (the logarithm of) is the export product share of the partner countries in year $t$; it measures the openness to transport services. The data were collected from World Integrated Trade Solution (WITS).

LNTSSGDP $_{t}$ (the logarithm of) is the trade services share in the GDP of the partner country in year t; it measures the services trade openness. The data were collected from World Bank database.

LNTSSIMPt $_{t}$ (the logarithm of) is the transport services share in the imports of the partner country in year $t$; it measures the importance of transport services imports for the receiving countries. The data were collected from World Integrated Trade Solutions (WITS).

LNUNEMPt $_{t}$ (the logarithm of) is the unemployment rate in the partner country in year $t$, it measures the labour foreign demand. The data were collected from World Bank database.
All the above independent variables are expected to have coefficients with positive signs.

LNCP $_{t}$ (the logarithm of) is the consumer prices of the partner countries in year $t$, measuring the purchase power. The data were collected from World Bank database.

LNDIST (the logarithm of) is the geographical distance between the capital cities of Romania and of the partner country; it is considered a proxy for transport costs. The distances were collected using the distance calculator.

LNCP and LNDIST are expected to have negative coefficients.

The dummy dichotomic variables used are:

CB (common border), it takes the value 1 if Romania and the partner country are sharing a common border and 0 otherwise.

CL (common language), it takes the value 1 if Romania and the partner country share a common language and 0 otherwise.

EU (European Union), it takes the value 1 when Romania and the partner country are members of EU and 0 otherwise.

LL (landlocked country), it takes the value 1 if the partner country is landlocked and 0 otherwise.

All the dummy variables, except for LL, are expected to have coefficients with positive signs, while LL is expected to have negative sign.

$\mathrm{t}$ is the year and it takes the whole values between 2007 and 2018.

$\varepsilon$ is the error term.

The Logistic Performance Index was realized just for the years 2007, 2010, 2012, 2014, 2016, 2018; therefore, for these years the H7 hypothesis was tested. In this case, the gravity equation would be:

LNEXPVAL $_{t}=\mathrm{C}+\mathrm{c}_{1}$ LNGDPP $_{\mathrm{t}}+\mathrm{c}_{2}$ LNDIST $_{+}$ $\mathrm{C}_{3}$ LNEXPPRODS $_{\mathrm{t}}+\mathrm{c}_{4}$ LNTSSGDP $_{\mathrm{t}}+$ $\mathrm{c}_{5}$ LNTSIMP $_{\mathrm{t}}+\mathrm{c}_{6}$ LNUNEMP $_{\mathrm{t}}+\mathrm{c}_{7}$ LNCP $_{\mathrm{t}}+\mathrm{c}_{8}$ 
$\mathrm{CB}+\mathrm{C}_{9} \mathrm{CL}+\mathrm{C}_{10} \mathrm{EU}+\mathrm{C}_{11} \mathrm{LL}+$ $\mathrm{C}_{12}$ LNCOMPADV $_{\mathrm{t}}+\mathrm{C}_{13} \mathrm{LNLPI}_{\mathrm{t}}+\varepsilon$

Where the new introduced variables will be:

LNCOMPADV $_{t}$ (the logarithm of) is the comparative advantage for Romania regarding the partner country in year $t$. The data were collected from World Integrated Trade Solutions (WITS). It is expected to have a positive sign.

LNLPI $_{t}$ (the logarithm of) is the Logistic Performance Index of the partner country in year t. The data were collected from World Bank database. It is expected to have a positive sign.

t takes the following values: 2007, 2010, 2012, 2014, 2016, 2018.

Using a panel data approach can control the possibility that the unobserved effects might correlate with the regressors (Egger, 2005). Baldwin and Taglioni (2006) recommended using either exports or imports and not the bilateral trade.

\section{The Results}

Table 2: The regression results

\begin{tabular}{|c|c|c|c|}
\hline Coefficients & $\begin{array}{c}\text { Panel Least Squares } \\
\text { Cross section SUR }\end{array}$ & $\begin{array}{c}\text { Panel Least Squares } \\
\text { Cross section fixed } \\
\text { effects }\end{array}$ & $\begin{array}{c}\text { Robust Least } \\
\text { Squares }\end{array}$ \\
\hline $\mathrm{C}$ & $-21.91^{*}$ & $-21.31^{*}$ & $-20.65^{*}$ \\
\hline LNGDPP $_{\mathrm{t}}$ & $1.19^{*}$ & $1.1^{*}$ & $1.09^{*}$ \\
\hline LNDIST $^{*}$ & $-0,11^{* *}$ & $-0.04^{* * *}$ & $-0,04^{*}$ \\
\hline LNEXPPRODS $_{\mathrm{t}}$ & $0.98^{*}$ & $1.04^{*}$ & $1.06^{*}$ \\
\hline LNTSSGDP $_{\mathrm{t}}$ & $0.84^{*}$ & $0.99^{*}$ & $0.96^{*}$ \\
\hline LNTSSIMP $_{\mathrm{t}}$ & $0.22^{* * *}$ & $0.46^{*}$ & $0.41^{*}$ \\
\hline LNUNEMP $_{\mathrm{t}}$ & $0.57^{*}$ & $0.97^{*}$ & $1^{*}$ \\
\hline LNCPt & -0.01 & $-0.15^{*}$ & -0.12 \\
\hline $\mathrm{CB}$ & $2.62^{*}$ & $2.42^{*}$ & $2.37^{*}$ \\
\hline $\mathrm{CL}$ & $1.04^{* *}$ & $1.4^{*}$ & $1.36^{*}$ \\
\hline $\mathrm{EU}$ & $1.31^{*}$ & $1.3^{*}$ & $1.26^{*}$ \\
\hline $\mathrm{LL}$ & $0.32^{* *}$ & 0.12 & 0.14 \\
\hline $\mathrm{R} \mathrm{Squared}$ & 0.78 & 0.80 & 0.69 \\
\hline
\end{tabular}

Legend: ${ }^{*}, * *{ }^{* * *}$ means that the results are statistically significant at $1 \%, 5 \%, 10 \%$ level

Source: Author's table based on EViews outputs

All the coefficients have the expected signs, except the ones for LL, which proved to be positive and they are statistically significant, except the ones for LL and LNCP in two models each.

The GDP of the partner country has the expected positive sign, with similar values, slightly over 1 .

The geographical distance between countries has a negative influence, though the value is quite low, which is consistent with the statistical results and the fact that between $77 \%$ and $92 \%$ of the Romanian transportation exports go to EU countries.

Among the most powerful drivers of the transportation exports are the export product share and the share of services trade in the GDP of the partner countries, the coefficients being closed to 1 in all models.

The unemployment rate of the receiving country and the share of the transportation services in the receiving country imports have a significant influence on the

Anca TAMAS, Journal of Eastern Europe Research in Business and Economics, DOI: $10.5171 / 2021.359892$ 
transportation export flows, but the coefficients for unemployment rate are twice as the ones for imports share.

The consumer price index has negative signs as expected, but it is statistically significant only in the second model.

Among the dummy variables, the similar culture, the common border and the common language have the expected positive signs and values, the coefficients for sharing a common border over 2 and for sharing a common language over 1 .

The EU membership has a positive influence on the transportation export flows, while the Landlocked variable has positive values and it is significant only in the first model.

Table 3: The regression results with LPI

\begin{tabular}{|c|c|c|c|}
\hline Coefficients & $\begin{array}{c}\text { Panel Least Squares } \\
\text { Cross section SUR }\end{array}$ & $\begin{array}{c}\text { Panel Least Squares } \\
\text { Cross section fixed } \\
\text { effects }\end{array}$ & $\begin{array}{c}\text { Robust Least } \\
\text { Squares }\end{array}$ \\
\hline $\mathrm{C}$ & $-21.96^{*}$ & $-19.01^{*}$ & $-18.43^{*}$ \\
\hline LNGDPP $_{\mathrm{t}}$ & $1.1^{*}$ & $1.01^{*}$ & $1.008^{*}$ \\
\hline LNDIST & -0.05 & -0.03 & -0.04 \\
\hline LNEXPPRODS $_{\mathrm{t}}$ & $0.97^{*}$ & $1.02^{*}$ & $1.03^{*}$ \\
\hline LNTSSGDPt $_{t}$ & $0.76^{*}$ & $0.87^{*}$ & $0.87^{*}$ \\
\hline LNTSSIMP $_{t}$ & $0.43^{*}$ & $0.45^{*}$ & $0.36^{* *}$ \\
\hline LNUNEMP $_{\mathrm{t}}$ & $0.77^{*}$ & $0.99^{*}$ & 0.98 \\
\hline $\mathrm{LNCP}_{\mathrm{t}}$ & -0.007 & $-0.19^{*}$ & -0.12 \\
\hline $\mathrm{CB}$ & $2.88^{*}$ & $2.35^{*}$ & $2.23^{*}$ \\
\hline$\overline{C L}$ & 1.12 & $1.51^{*}$ & $1.46^{*}$ \\
\hline$E U$ & $1.21^{*}$ & $1.23^{*}$ & $1.20^{*}$ \\
\hline LL & 0.07 & 0.04 & 0.15 \\
\hline LNCOMPADV $_{\mathrm{t}}$ & 0.03 & $0.14^{* *}$ & $0.14^{*}$ \\
\hline LNLPIt & $1.23^{* *}$ & 0.54 & 0.33 \\
\hline R squared & 0.78 & 0.80 & 0.69 \\
\hline
\end{tabular}

Legend: *,**,** means that the results are statistically significant at $1 \%, 5 \%, 10 \%$ level

Source: Author's table based on EViews outputs

Some differences in the second set of results compared to the first one are to be noticed:

The distance between countries became statistically insignificant, although it has the same negative sign and the similar small values.

The share of services trade in the GDP of the partner countries is a bit lower and the share of the transportation services in the imports of the partner country is a bit higher.

The consumer price index in the receiving countries became significant in the second model and Landlocked became statistically insignificant in all models.
For GDP, Export Product Share, Unemployment Rate, Common Border, Common Language, EU membership, the signs are the same and the values are similar with the ones in the first set of results.

For the new tested variables, the comparative advantage has the expected sign and small values and it is statistically significant only for the second and the third model, while Logistic Performance Index of the partner country has the expected sign; it is significant in the first model with a high value and insignificant in the other two models with smaller values. 
Based on the coefficients from the gravity equation, the potential transportation exports were competed and compared with the real transportation exports. The results showed that the potential exports are greater than the real ones.

\section{Conclusions}

Both the GDP and the GDP per capita of the partner country, as well as the total GDP and the total GDP per capita of Romania and of the partner country, were tested, but the best explanatory power was the one of the GDP of the receiving country. The results are similar with the findings of Grunfeld and Moxnes (2003), in contradiction with the results of Walsh (2006) and extending the findings of Francois (2001) for exports as well. Therefore, the first research hypothesis is sustained, the greater the economic size of the partner country is, the greater the need for transportation it will have, so more opportunities for transportation imports are.

The geographical distance between Romania and the partner country has a negative impact on the Romanian transportation export flows, which is consistent with the fact that most of the Romanian transportation goes to EU countries, therefore the distances are not too large. The results for the significance of the distance are similar to the ones of Park (2002), contradicting the findings of Yamaguchi (2008). The coefficients for distance are much smaller than the ones in the goods flows, in line with the results of Lejour and de Paiva Verheijden (2004) and Walsh (2006). So, the second research hypothesis is sustained for the first set of results and not sustained for the second set of results. Since the first set is a complete panel database, the $\mathrm{H} 2$ hypothesis was considered sustained.

The third research hypothesis is confirmed and the major drivers of the Romanian transportation export flows are the openness to transport services and the services trade openness of the partner country.
The fourth research hypothesis is sustained and the unemployment rate of the receiving country is found to be an important predictor of the Romanian transport exports.

The fifth research hypothesis is confirmed. EU membership proved to be a major driver for Romanian transportation exports, thus sustaining the results of Kimura and Lee (2006) and Nordas (2018) and contradicting the results of Walsh (2006). The common border is an important predictor, with the highest value of all variables, once more this is confirming the findings of Nordas (2018) and contradicting the ones of Walsh (2006). Sharing a common language is found important for Romanian transportation export flows, in line with the results of Park (2002), Kox and Lejour (2005), Walsh (2006), Tsui and Fung (2016), Nordas (2018) and in contradiction with the ones of Kimura and Lee (2006).

The sixth hypothesis is rejected, although the Consumer Price Index has the expected negative influence, it is not statistically significant in two out of three models. As for the Landlocked dummy variable, although seen as a measure of remoteness, it is not statistically significant, nor has the expected negative sign, the results sustain the findings of Covaci and Moldovan (2015).

The last research hypothesis is rejected, although the comparative advantage and the Logistic Performance Index have the expected signs, they are not statistically significant in all models or the values are too small. The results are in contradiction with the findings of Alaveras and Martens (2015) and Host et. al (2019).

As the potential transportation exports are greater than the real transportation exports, there is enough room to improve the exports for these particular kinds of services.

All in all, the gravity model explained very well the Romanian transportation export flows from 2007 to 2018, considering the

Anca TAMAS, Journal of Eastern Europe Research in Business and Economics, DOI: $10.5171 / 2021.359892$ 
high values of $\mathrm{R}$ squared, confirming the results of van Bergeijk and Brakman (2011).

It seems somehow natural that the results of different empirical studies be apparently contradictory, because the trade flows are highly sensitive to the specific characteristics of the trade countries.

\section{References}

- Alaveras, G. and Martens, B. (2015), International Trade in Online Services, Institute for Prospective Technological Studies, Digital Economy Working Paper $(2015$ - 08).

- Anderson, J. E. (1979, February), 'A Theoretical Foundation for Gravity Equation', American Economic Review, 69 (1), 106-116.

- Anderson, J. E. (2010, December), The Gravity Model, The National Bureau of Economic Research, NBER Working Paper No. 16576, (DOI): 10.3386/w16576.

- Anderson, J. E. and van Wincoop, E. (2003, March), 'Gravity with Gravitas: A Solution to the Border Puzzle', American Economic Review, 93 (1), 170-192, DOI: $10.1257 / 000282803321455214$.

- $\quad$ Baier, S. L. and Bergstrand, J. H. (2001, February), 'The Growth of World Trade: Tariffs, Transport Costs, and Income Similarity', Journal of International Economics, 53 (1), 1-27, DOI: $10.1016 / S 0022-1996(00) 00060-$ X.

- Baldwin, R. and Taglioni, D. (2006, September), Gravity for Dummies and Dummies for Gravity Equations, The National Bureau of Economic Research (NBER), NBER Working Paper No. 12516, (DOI): 10.3386/w12516.

- Bergstrand, J. H. (1985), 'The Gravity Equation in International Trade: Some Microeconomic Foundations and Empirical Evidence', The Review of Economics and Statistics, 67 (3), 474481.

- Borchert, I., Gootiiz, B. and Mattoo, A. (2012, June), 'Policy Barriers to International Trade in Services:
Evidence from a New Database', The World Bank Economic Review, 28 (1), DOI: $10.1093 /$ wber/lht017.

- Brun, J.-F, Carrère, C., Guillaumont, P. and De Melo, J. (2005), 'Has Distance Died? Evidence from a Panel Gravity Model', World Bank Economic Review, 19 (1), 99-120, DOI: $10.1093 /$ wber/lhi004.

- Covaci, G. and Moldovan, S. (2015, November), 'Determinants of Service Exports of Lithuania: A Gravity Model Approach', SSE Riga Student Research Papers, 1 (166), Stockholm School of Economics.

- Deardorff, A. (1998, January), Determinants of Bilateral Trade: Does Gravity Work in a Neoclassical World?, The Regionalization of the World Economy, Frankel, J. A. (ed.), pp. 7-32, University of Chicago Press.

- Egger, P. (2005, November), 'Alternative Techniques for Estimation of Cross-Section Gravity Models', Review of International Economics, 13 (5), 881-891, https://doi.org/10.1111/i.14679396.2005.00542.x.

- Egger, P. (2008, May), 'On the Role of Distance for Bilateral Trade', The World Economy, 31 (5), 653-662, https://doi.org/10.1111/j.14679701.2008.01098.x.

- $\quad$ Evenett, S. and Keller, W. (2002), ‘On Theories Explaining the Success of the Gravity Equation', Journal of Political Economy, $110 \quad$ (2), 281-316, http://dx.doi.org/10.1086/338746.

- Feenstra, R. C. (2003, February), 'Border Effects and the Gravity Equation: Consistent Methods for Estimation', Scottish Journal of Political Economy, 49 (5), 491-506, https://doi.org/10.1111/14679485.00244.

- Francois, J. (2001), The Next WTO Round: North-South Stakes in New Market Access Negotiations, Adelaide: Centre for International Economic Studies.

- Francois, J., van Meijl, H. and van Tongeren, F. (2003), Economic Benefits of the Doha Round for the Netherlands, 
The Hague: Agricultural Economics Institute.

- Grünfeld, L. A. and Moxnes, A. (2003), The Intangible Globalization: Explaining the Patterns of International Trade in Services, Norwegian Institute of International Affairs, No. 657.

- Head, K. (2003, February), 'Gravity for Beginners', UNCTAD. [Online], [Retrieved July 1, 2020], https://vi.unctad.org/tda/background /ntroduction $\% 20$ to $\% 20$ Gravity $\% 20 \mathrm{M}$ odels/gravity.pdf

- Head, K. and Mayer, T. (2014), 'Gravity Equations: Workhorse, Toolkit, and Cookbook', Handbook of International Economics, 4, 131-195.

- Helpman, E. (1987), 'Imperfect Competition and International Trade: Evidence from Fourteen Industrial Countries', Journal of the Japanese and International Economies, 1, 62-81.

- Host, A., Skender, H. P. and Zaninovic, P. A. (2019, June), 'Trade Logistics - the Gravity Model Approach', Proceedings of Rijeka School of Economics, 37 (1), 327-342,

DOI: $10.18045 /$ zbefri.2019.1.327.

- International Trade Center, https://www.intracen.org/itc/marketinfo-tools/trade-statistics/.

- Kimura, F. and Lee, H.-H. (2006, February), 'The Gravity Equation in International Trade in Services', Review of World Economics, 142 (1), 92-121, DOI: $10.1007 / \mathrm{s} 10290-006-0058-8$.

- Kox, H. L. M. and Lejour, A. (2005, February), Regulatory Heterogeneity as Obstacle for International Services Trade, CPB Netherlands Bureau for Economic Policy Analysis.

- Krugman, P. R. (1980, December), 'Scale Economies, Product Differentiation, and the Pattern of Trade', American Economic Review, 70, 950-959.

- Lejour, A. and de Paiva Verheijden, J.W. (2004, December), Services trade within Canada and the European Union; What do they have in common?, CPB Netherlands Bureau for Economic
Policy Analysis, CPB Discussion Paper No. 42.

- Martinez-Zarzoso, I. and SuarezBurguet, C. (2005), 'Transport costs and trade: Empirical evidence for Latin American imports from the European Union', The Journal of International Trade \& Economic Development, 14 (3), 353-371,

http://www.tandfonline.com/doi/abs/ 10.1080/09638190500212121.

- Nordas, H. K. (2018, January), 'What drives trade in services? Lessons from the Nordics', Applied Economics, 50 (33), 3532-3545, https://doi.org/10.1080/00036846.20 18.1430334.

- Park, S.-C. (2002), Measuring Tariff Equivalents in Cross-Border Trade in Services, Korea Institute for International Economic Policy Working Paper, No. 02-15.

- $\quad$ Rose, A. K. and Spiegel, M. M. (2004), A Gravity Model of Sovereign Lending: Trade, Default, and Credit, International Monetary Fund, Vol. 51, Special Issue, https://www.imf.org/external/pubs/ft /staffp/2003/00-00/rs.pdf.

- Tharakan, P. K. M., Van Beveren, I. and Van Ourti, T. (2005, November), 'Determinants of India's Software Exports and Goods Exports', The Review of Economics and Statistics, 87 (4), 776-780.

- Tinbergen, J. (1962), Shaping the World Economy; Suggestions for an International Economic Policy, Twentieth Century Fund, New York.

- Tsui, K. and Fung, M. K. Y. (2016, February), ,Causality between business travel and trade volumes: Empirical evidence from Hong Kong', Tourism Management, 52, 395-404, DOI: 10.1016/j.tourman.2015.07.010.

- van Bergeijk, P. A. G. and Brakman, S. (2011, June), The Gravity Model in International Trade: Advances and Applications, Cambridge University Press,

https://doi.org/10.1017/CB09780511 762109.

- Walsh. K. (2006, November), Trade in Services: Does Gravity Hold? A Gravity

Anca TAMAS, Journal of Eastern Europe Research in Business and Economics, DOI: $10.5171 / 2021.359892$ 
Model Approach to Estimating Barriers to Services Trade, IIIS Discussion Paper Series

No.

183,

http://dx.doi.org/10.2139/ssrn.94533 $\underline{5}$.

- World

Bank, https://data.worldbank.org .

- World Integrated Trade Solution, https://wits.worldbank.org .
- Yamaguchi, K. (2008, July), 'International trade and air cargo: Analysis of US export and air transport policy', Transportation Research Part E Logistics and Transportation Review, 44 (4), 653-663, DOI: 10.1016/j.tre.2007.05.006. 